\title{
Study on the Construct of Business Model Innovation
}

\author{
Hao Ding, Bingcheng Wang \\ College of Economic and Management, China University \\ of Petroleum (East China) \\ Qingdao, China \\ dinghao@upc.edu.cn
}

\author{
Bingcheng Wang, Fang Yang \\ College of Economic and Management, Shandong \\ University of Science and Technology \\ Qingdao, China \\ qdwbc@163.com
}

\begin{abstract}
The measurement of business model innovation is the basis of empirical research of business model innovation, but the studies of business model innovation are basically using the method of theoretical analysis and case studies, and lack of empirical research questionnaires. In this paper, the questionnaire of business model innovation is developed through many stages, such as literature review, expert interviews, pre-research and formal research. Then the authors use the method of exploratory factor analysis to identify the constructs of the questionnaire, and obtain two factors which are business model creativity and business model application. Based on this, the authors use the method of structural equation model and confirmatory factor analysis to test the questionnaire's validity. The result shows that the model of two factors is suitable, and it can be used in future's empirical studies.
\end{abstract}

Keywords- business model innovation; factor analysis; structural equation model

\section{INTRODUCTION}

In today's rapidly changing business environment, the source of sustainable competitive advantage is often obtained from business model innovation(Voelpel, Leibold \& Tekie, 2004)[1]. Research literature shows that business model innovation has become the research focus of scholars in the field of strategic management, and scholars have a growing interest in it(Aspara, Hietanen \& Tikkanen, 2010; Zott, Amit \& Massa, 2011)[2, 3]. However, the studies of business model innovation are basically using the method of theoretical analysis and case studies, and lack of empirical research, and we can only find these rare articles, such as Aziz \& Mahmood(2008)[4], Brettel, Strese \& Flatten(2012)[5] and Zott \& Amit(2007, 2008)[6' 7], One important reason for this is the lack of empirical research tools of business model innovation, such as the measurement of business model innovation, and the purpose of this paper is to remedy this deficiency in order to facilitate the empirical research of business model innovation.

\section{LITERATURE REVIEW}

Throughout the study at home and abroad, we can find that the current research on business model innovation is essentially focused on the object of study (object-based), which focuses on business model innovation
itself(Archibugi \& Sirilli, 2001)[8]. For example, some scholars are concerned about how to give an concept of business model innovation that can be widely accepted by academia and business( Bucherer, Eisert \& Gassmann, 2012; Casadesus-Masanell \& Zhu, 2011; Ho, Fang \& Hsieh, 2011; Mason \& Leek, 2008)[9-12], another part of the scholars are concerned about the classification of business model innovation(Koen, Bertels \& Elsum et al., 2010; Giesen, Berman, Bell \& Blitz, 2007; Smedlund, 2012)[13-15], and there are still some scholars are concerned about the phasing of business model innovation(Casadesus-Masanell \& Ricar, 2010; Cavalcante, Kesting \& Ulhøi, 2011; Schaltegger, Lüdeke-Freund \& Hansen, 2011)[16-18].

The study of business model innovation based on the subject(subject-based) was less involved. The study of subject-based business model innovation mainly focuses on the role of actors, trying to discover how these actors can innovate more effective and efficient(de Jong, 2007)[19], its levels including nation, industry, organizations, groups and individuals(de Jong \& Vermeulen, 2005)[20]. Current research is only launched from the perspective of nation and industry, such as Casadesus-Masanell \& Ricar (2010), Teece(2010) [21], etc., but the study of individual-level that is particularly important has not yet been found. And individual employees in an organization is the real source of business model innovation, after all, the organization is constituted by the people, and the organization itself does not generate business model innovation.

The subject-based business model innovation includes business model creativity and business model application, but the current study shows the research questionnaires in this area is still insufficient, and hindering the development of related research. According to business practices, by using the viewpoint of learning school of Mintzberg et al. (1989) and Darwin's theory of evolution view, this paper thought that business model innovation is produced by the primary management personnel, and mainly grass-roots management personnel innovates business model, because grass-roots management is the closest to the market and most familiar with the emerging market trends. Of course, this is not to deny the role of senior management, due to the limited rationality, senior managers cannot pre-designed a perfect business model for grass-roots management personnel, they play a major role in the convergence and advocacy, and middle management staff will play a connecting and upload assigned role (Nonaka \& Takeuchi, 1995). Therefore, this study mainly in the sample of grass- 
roots management, targeted at the development of individual-level research questionnaires of business model innovation, and it can be used in future's empirical studies.

\section{METHOD}

\section{A. Questionnaire Design}

Business model innovation questionnaire refers many other studies, such as Scott \& Bruce (1994), Kleysen \& Street (2001), Rice (2006) [22], Chan Shuling (2006), de Jong (2007) et al, Designed 13 items, such as "I will issue new ideas or solutions for the problems of the current business model ","I will go to assess the advantages and disadvantages of new business models", "I will go to explore opportunities which will improve the business model of company or department", "I will apply new business models in the daily routine of work ", all the items use the attitude Scale and are measured by Likert five-point scale.

\section{B. Data Processing Method}

After the questionnaires were collected, using SPSS15.0 for sample descriptive statistics, exploratory factor analysis, common test, reliability analysis, using structural equation model for confirmatory factor analysis through Amos7.0 .

\section{RESULTS OF BUSINESS MODEL INNOVATION CONSTITUTE}

\section{A. Sample}

In this study, 700 questionnaires were distributed, 561 were recovered, 63 invalid questionnaires were excluded,
498 valid questionnaires were obtained, the effective rate was $71.14 \%$.

\section{B. Exploratory Factor Analysis of Business Model Innovation}

Table 1 shows that Kaiser-Meyer-Olkin (KMO) value of business model innovation questionnaire is 0.900 , approximate chi-square value of Bartlett's Test of Sphericity is 1875.583 , and the degree of freedom is $55, \mathrm{p}<0.001$, these indicate that factor analysis is suitable.

\section{TABLEI. KMO AND BARTLETT'S TEST}

\begin{tabular}{llc}
\hline Kaiser-Meyer-Olkin Measure of Sampling Adequacy & 0.900 \\
Bartlett's Test of Sphericity & Approx. Chi-Square & 1875.583 \\
& $d f$ & 55 \\
Sig. & 0.000
\end{tabular}

By using principal factor analysis, the 11 items on the questionnaire are made orthogonal rotation, according to the proposal of Kaiser (1970), extracting factors in which eigenvalues are greater than one, as shown in Table 2, questionnaires extracted two common factors, eigenvalues are 4.786 and $1.389,56.143 \%$ of the total variance can be explained.

TABLEII. TOTAL VARIANCE EXPLAINED

\begin{tabular}{|c|c|c|c|c|c|c|c|c|c|}
\hline & \multicolumn{3}{|c|}{ Initial Eigenvalues } & \multicolumn{3}{|c|}{ Extraction Sums of Squared Loadings } & \multicolumn{3}{|c|}{ Rotation Sums of Squared Loadings } \\
\hline & Total & \% of Variance & Cumulative \% & Total & $\%$ of Variance & Cumulative \% & Total & \% of Variance & Cumulative \% \\
\hline 1 & 4.786 & 43.512 & 43.512 & 4.786 & 43.512 & 43.512 & 3.275 & 29.769 & 29.769 \\
\hline 2 & 1.389 & 12.632 & 56.143 & 1.389 & 12.632 & 56.143 & 2.901 & 26.374 & 56.143 \\
\hline 3 & .757 & 6.880 & 63.024 & & & & & & \\
\hline 4 & .668 & 6.071 & 69.094 & & & & & & \\
\hline 5 & .628 & 5.712 & 74.806 & & & & & & \\
\hline 6 & .549 & 4.987 & 79.794 & & & & & & \\
\hline 7 & .493 & 4.482 & 84.276 & & & & & & \\
\hline 8 & .473 & 4.297 & 88.573 & & & & & & \\
\hline 9 & .452 & 4.113 & 92.686 & & & & & & \\
\hline 10 & .447 & 4.064 & 96.750 & & & & & & \\
\hline 11 & .357 & 3.250 & 100.000 & & & & & & \\
\hline
\end{tabular}


Hair et al.(1998) pointed out that the factor loadings should be greater than 0.3 , preferably greater than 0.5 , the items that do not meet the conditions should be deleted. In this study, the rotation component matrix is shown in Table 3 , in order to clear, factor loading values that are less than 0.3 are not shown in the table 3 .

\section{TABLEIII. ROTATION COMPONENT MATRIX}

\begin{tabular}{lccc}
\hline & \multicolumn{2}{c}{ Element } & $\begin{array}{c}\text { Cronbach's } \\
\boldsymbol{\alpha}\end{array}$ \\
\cline { 2 - 4 } & $\begin{array}{c}\text { business model } \\
\text { application }\end{array}$ & business model creativity \\
\hline T11 & 0.757 & 0.828 \\
T12 & 0.746 & \\
T14 & 0.710 & & \\
T10 & 0.706 & & \\
T13 & 0.647 & 0.364 & \\
T8 & 0.634 & 0.809 & \\
T2 & & 0.790 & \\
T3 & & 0.714 & \\
T1 & & 0.616 & \\
T7 & 0.305 & 0.601 & \\
T5 & 0.381 & & \\
\hline
\end{tabular}

As can be seen from the table 3, the factor loadings of each item cannot appear more than 0.5 or less than 0.5 simultaneously in the correlation factor, the relevant questions of the factor loadings are above 0.6 in the corresponding factor, indicating that the questionnaire meets convergent validity and discriminant validity. Then, based on the items of two business model innovation factors, we will name the first factor as business model application and the second factor as business model creativity, as shown in Table 3.

\section{Confirmatory Factor Analysis of Business Model Innovation}

To further verify the results of exploratory factor analysis, we use confirmatory factor analysis for results through Amos7.0. Meanwhile we test structure validity of single factor and two-factor of business model innovation. Confirmatory factor analysis model of Two-factor model is shown in Figure 1. It can also be seen from the figure that the factor loadings of each item are more than $0.6, \mathrm{P}<0.001$, indicating that all factor loadings are in an acceptable range.

Related indicators of model adaptation is shown in Table 4. From the table we can see that the relevant indicators of single factor model does not fully meet the requirements, and indicators in the two-factor model, such as the ratio of Chi-square value and freedom degree, GFI, AGFI, CFI, TLI, IFI, RMSEA, etc. have reached the relevant requirements, these show that two-factor model has good construct validity.

TABLEIV. MODEL FIT INDEX

\begin{tabular}{cccccccccc}
\hline & $\chi^{2}$ & $d f$ & $\chi^{2} / d f$ & GFI & AGFI & CFI & TLI & IFI & RMSEA EA \\
\hline single-factor model & 459.417 & 77 & 5.966 & 0.858 & 0.806 & 0.865 & 0.840 & 0.865 & 0.100 \\
two-factor model & 162.461 & 43 & 3.778 & 0.944 & 0.914 & 0.936 & 0.918 & 0.937 & 0.075 \\
\hline
\end{tabular}




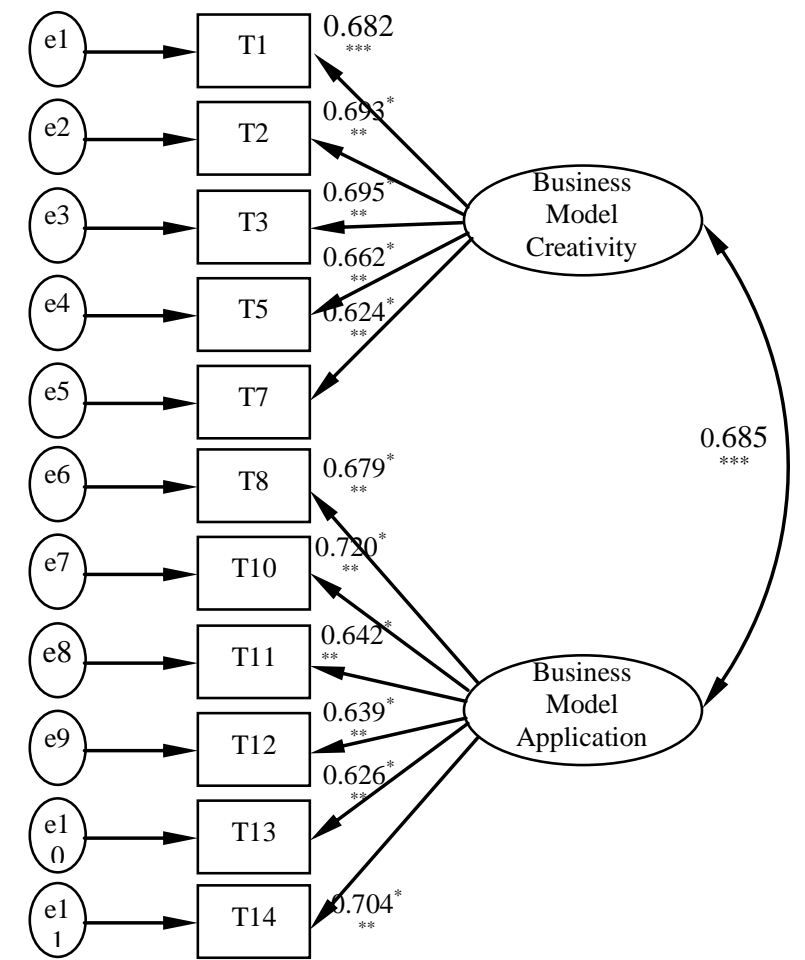

Fig.1 Confirmatory Factor Analysis of Business Model Innovation

\section{Reliability Test of Various Dimensions of Business Model Innovation}

On this basis, we have tested the reliability of two factors. Reliability that is tested by Cronbach's $\alpha$ coefficient represents the consistency or stability of the scale, in general, it is believable until reliability is above 0.7. The Cronbach's $\alpha$ of business model creativity is 0.802 , the Cronbach's $\alpha$ of business model application is 0.828 . So the results are fit to next research.

\section{CONClusions AND SignificANCE}

The measurement of business model innovation is the basis of empirical research of business model innovation. In this paper, the questionnaire of business model innovation is developed through many stages, such as literature review, expert interviews, pre-research and formal research. Then the authors use the method of exploratory factor analysis to identify the constructs of the questionnaire, and obtain two factors which are business model creativity and business model application. Based on this, the authors use the method of structural equation model and confirmatory factor analysis to test the questionnaire's validity, the results showed that the design of the questionnaire meets the requirements of the relevant indicators, and it will be applied to future's empirical studies.

However, the studies of business model innovation at home and abroad are basically using the method of theoretical analysis and case studies, and lack of empirical research, but the research questionnaire of business model innovation in this paper not only enriches related research, but also can be used in future's empirical studies.

\section{REFERENCES}

[1] Voelpel, S.C., Leibold, M., Tekie, E.B, "The Wheel of Business Model Reinvention: How to Reshape Your Business Model to Leapfrog Competitors," Journal of Change Management, vol. 4, No. 3, 2004, pp. 259,-276.

[2] Aspara, J., Hietanen, J., Tikkanen, H., "Business Model Innovation vs Replication: Financial Performance Implications of Strategic Emphases," Journal of Strategic Marketing, vol. 18, No. 1, 2010 pp. 39-56.

[3] Zott, C., Amit, R., Massa, L., "The Business Model: Recent Developments and Future Research," Journal of Management, vol. 37, No. 4, 2011, pp. 1019-1042.

[4] Aziz, S.A., Fitzsimmons, J., Douglas, E., "Clarifying the Business Model Construct," AGSE, 2008.

[5] Brettel, M., Strese, S., Flatten, T. C. "Improving the Performance of Business Models with Relationship Marketing Efforts - An Entrepreneurial Perspective," European Management Journal, vol. 30, No. 2, 2012, pp. 85-98.

[6] Zott, C., Amit, R. "Business Model Design and the Performance of Entrepreneurial Firms," Organization Science, vol. 18, No. 2, 2007, pp. 181-199.

[7] Zott, C., Amit, R. "The Fit between Product Market Strategy and Business Model: Implications for Firm Performance," Strategic Management Journal, vol. 29, No. 1, 2008, pp. 1-26.

[8] Archibugi, D., Sirilli, G. "The Direct Measurement of Technological Innovation in Business: The State of the Art," In: Thuriaux, B., Arnold, E., Couchot, C. Innovation and Enterprise Creation. Luxembourg: European Commision, 2001, pp. 38-49.

[9] Bucherer, E., Eisert, U., Gassmann, O. "Towards Systematic Business Model Innovation: Lessons from Product Innovation Management," Creativity and Innovation Management, vol. 21, No. 2, 2012, pp. 183198.

[10] Casadesus-Masanell, R., Zhu, F. "Business Model Innovation and Competitive Imitation: The Case of Sponsor-Based Business Models," Working Paper(11-003), Harvard Business School, 2011.

[11] Ho, Y.C., Fang, H.C., Hsieh, M.J. "The Relationship between Business-model Innovation and Firm Value: A Dynamic Perspective," World Academy of Science, Engineering and Technology, vol. 77, 2011, pp. 656-664.

[12] Mason, K.J., Leek, S. "Learning to Build A Supply Network: An Exploration of Dynamic Business Models," Journal of Management Studies, vol. 45, No. 4, 2008, pp. 774-799.

[13] Koen, P.A., Bertels, H., Elsum, I.R., et al. "Breakthrough Innovation Dilemmas," Research, Technology Management, vol. 53, No. 6, 2010, pp. 48-51.

[14] Giesen, E., Berman, S.J., Bell, R., Blitz, A. "Three Ways to Successfully Innovate Your Business Model," Strategy \& Leadership, vol. 35, No. 6, 2007, pp. 27-33.

[15] Smedlund, A. "Value Cocreation in Service Platform Business Models," Service Science, vol. 4, No. 1, 2012, pp. 79-88.

[16] Casadesus-Masanell, R., Ricart, J.E. "From Strategy to Business Models and onto Tactics," Long Range Planning, vol. 43, No. 2-3, 2010, pp. 195-215.

[17] Cavalcante, S., Kesting, P., Ulhøi, J. "Business Model Dynamics and Innovation: (Re)establishing the Missing Linkages," Management Decision, vol. 49, No. 8, 2011, pp. 1327-1342.

[18] Schaltegger, S., Lüdeke-Freund, F., Hansen, E.G. "Business Cases for Sustainability and the Role of Business Model Innovation: Developing a Conceptual Framework," Centre for Sustainability Management (CSM), Leuphana Universität Lüneburg, 2011. 
[19] de Jong, J.P.J. "Individual Innovation: The Connection Between Leadership and Employees' Innovative Work Behavior," Universiteit van Amsterdam, 2007.

[20] de Jong, J.P.J., Vermeulen, P.A.M. "Innovatie in Onderzoek En Onderwijs: Wat Leren Onze Studenten? (Innovation in Research and Education: What do Our Students Learn?)," Tijdschrift voor Hoger Onderwijs, vol. 43, No. 1, 2005, pp. 17-43.
[21] Teece, D.J. "Business Models, Business Strategy and Innovation," Long Range Planning, vol.43, No. 2-3, 2010, pp. 172-194.

[22] Rice, G. "Individual Values, Organizational Context, and Selfperceptions of Employee Creativity: Evidence from Egyptian Organizations," Journal of Business Research, vol. 59, No. 2, 2006, pp. 233-241. 